\title{
Does Eligibility for Tertiary Education Affect Crime Rates? Quasi-Experimental Evidence
}

\author{
Martin Nordin ${ }^{1}$
}

Published online: 19 May 2017

(C) The Author(s) 2017. This article is an open access publication

\begin{abstract}
Objectives This paper estimates the effect of tertiary education eligibility on crime in Sweden. The hypothesis tested is that continuing to higher education decreases crime rates since it allows young people to escape inactivity and idleness, which are known to trigger crime. However, to qualify for tertiary education, individuals have to meet the eligibility requirements in upper-secondary school. Tertiary education eligibility may therefore affect crime rates.

Methods This paper uses a panel data set of 287 Swedish municipalities over the period 1998-2010 to estimate the tertiary education eligibility effect on crime. However, estimating educational effects on crime is challenging, because investment in education is an endogenous decision. In Sweden, substantial grade inflation, increased tertiary education eligibility by more than $6 \%$ points between 1998 and 2003. Thus, since the eligibility increase is exogenous to the educational achievements of a student cohort, i.e. not accompanied by a corresponding knowledge increase, we can use the increase to identify the effect of tertiary education eligibility on crime.

Results It is found that increasing the tertiary education eligibility rate decreases both property and violent crime substantially.

Conclusions The results show that when young people have the opportunity to attend tertiary education, and thus escape unemployment or inactivity, their propensity to commit crime decreases.
\end{abstract}

Keywords Crime $\cdot$ Education · Tertiary eligibility $\cdot$ Attendance

JEL Classification I2 $\cdot$ K42

Martin Nordin

Martin.nordin@nek.lu.se

1 Department of Economics, Lund University, P.O. Box 7082, 22007 Lund, Sweden 


\section{Introduction}

Youth unemployment and inactivity is harmful, as it may result in deskilling and have a negative impact on the individual's future labour market experience (Bell and Blanchflower 2011; Ellwood 1982). For young people not eligible for tertiary education, being unemployed after leaving school at 19 decreases earnings and increases the risk of unemployment for at least the next 5 years (Nordström Skans 2011). On the other hand, for young people who attain eligibility for tertiary education during their upper-secondary schooling, going on to higher education is a way of avoiding unemployment or inactivity. Eligibility for tertiary education may therefore reduce youth inactivity and its negative externalities. A negative externality of unemployment that has received much attention is crime.

This study provides empirical evidence of a negative tertiary education eligibility effect on crime for Sweden. This effect is caused by tertiary education attendance that is not completely voluntary, but conditional on eligibility. Voluntary educational attendance effects (Tauchen et al. 1994) and educational incapacitation effects on crime have been investigated previously (Jacob and Lefgren 2003; Luallen 2006; Åslund et al. 2012; Anderson 2014) and have been found to affect crime rates, but tertiary education eligibility effects on crime rates have not been investigated. Because criminal behaviour peaks in late adolescence (see for example Hirschi and Gottfredson 1983; Hansen 2003; Åslund et al. 2012), tertiary education eligibility may reduce crime rates substantially.

However, estimating voluntary attendance and eligibility effects on crime is challenging, because investment in education is an endogenous decision. One problem is that criminal activity may influence educational attainment, resulting in reverse causation (Hjalmarsson 2008). Another is that unobserved individual characteristics affecting both educational attainment and crime might bias the attendance and eligibility effects. Thus, to identify a causal tertiary education eligibility effect, an eligibility variation that is exogenous to the educational achievement and criminal activity of the individual is needed.

In Sweden, substantial grade inflation occurred after a change to a goal-and criterionreferenced grading system in 1997. Grade inflation also affected tertiary education eligibility because students must achieve pass grades in $90 \%$ of their courses to obtain a certificate providing eligibility for tertiary education. Tertiary education eligibility subsequently increased by more than $6 \%$ points between 1998 and 2003 . Thus, since the eligibility increase is exogenous to the educational achievements of a student cohort, i.e. not accompanied by a corresponding knowledge increase (Björklund et al. 2010; Cliffordson 2004; Gustafsson and Yang Hansen 2009; Wikström and Wikström 2005), we can use the increase to identify the effect of tertiary education eligibility on crime. Using aggregate municipality data, in this paper we assess whether a larger proportion of eligible individuals affects crime rates in Swedish municipalities. When the problem of grade inflation was brought to public attention in 2004 as a result of investigation of the goal-and criterion-referenced grading system by the Swedish National Audit Office, grades and eligibility rates were set at the 2003 level.

Decreasing the tertiary education eligibility requirements makes tertiary education available to young people at the margin of eligibility. Because the number of student places at tertiary education establishments also increased during the period of grade inflation in Sweden, tertiary education generally became accessible to marginal students. In 2004, when the problem with grade inflation was resolved, the number of student places (relative to number of potential applicants) also decreased, meaning that it was more difficult for 
marginal students to enter tertiary education. Hence, here we use the post-inflation period to test whether the eligibility effect on crime is truly caused by young people attending tertiary education.

Decreasing the eligibility requirements reduces the barriers to tertiary education and thus affects the schooling investment decision. In fact, it makes tertiary education accessible to individuals who would have invested in tertiary education without the eligibility criteria, i.e. individuals with positive net utility from education. In a schooling system such as that in Sweden, where there are no tuition fees for tertiary education, the eligibility criterion is an actual barrier, whereas in a schooling system with high tuition fees, marginal students (the lower end of the upper-secondary grade distribution) are less likely to invest in tertiary education in any case.

\section{Literature Review}

Studies evaluating the causal impact of education on crime mainly use changes in schooling laws. Lochner and Moretti (2004) use changes in state compulsory schooling laws over time to identify the causal effect of education on crime. For the US, they reveal that education reduces the probability of incarceration and arrest. Machin et al. (2011) show that for England and Wales, changes in the compulsory school leaving age in the early 1970s reduced property crimes. In a recent study in Sweden, Hjalmarsson et al. (2013) use a reform in the 1950s, which extended compulsory schooling from 7 to 9 years but was implemented at different times in different regions, to estimate a causal educational effect on crime. They show that one additional year of schooling consistently decreases the probability of conviction and incarceration. Moreover, expansion of the UK post-compulsory education system in the 1980s and 1990s appears to have decreased crime rates (Machin et al. 2012). While these studies demonstrate a causal link between education and crime, other studies show an association (e.g. Sabates 2008, 2009; Sabates and Feinstein 2008).

To explain these results, education can first be assumed to increase the wage rate and thereby increase the opportunity cost of crime (Lochner and Moretti 2004). Studies by Gould et al. (2002), Grogger (1998) and Machin and Meghir (2004) support this explanation and show a negative relationship between wages and property crime. The propensity to commit crime also decreases if education reduces the discount rates of future wages (Lochner and Moretti 2004). To our knowledge, no study on this mechanism exists but, since upper-secondary school dropouts appear more myopic (Oreopoulos 2007), this explanation is plausible.

The mechanisms above perceive education as either productivity enhancing or preference altering, but education may also reduce the probability of young people being in crime-related circumstances (such as unemployment or inactivity). School attendance affects crime rates negatively through both a voluntary attendance effect and an incapacitation effect. For example, Tauchen et al. (1994) provide evidence that the percentage of years in education has a negative effect on the probability of arrest. Exogenous events, such as teachers' strikes (Jacob and Lefgren 2003) or teacher training days (Luallen 2006), has been used to identify the incapacitation effect. The incapacitation effect appears to decrease crime generally, and not only as a displacement of crime over time (Luallen 2006). Increasing the compulsory school leaving age by at least one additional year can reduce arrest rates by almost 10\% (Anderson 2014). Finally, Åslund et al. (2012) show an 
incapacitation effect on property crimes in Sweden of extending the vocational uppersecondary school programme from 2 to 3 years. The effect is mainly concentrated to the extra third year of education.

Felson (1998) proposes another mechanism, suggesting that idleness and less structured daily routines result in excess time and opportunities to engage in criminal activities. Idleness may also increase exposure to criminogenic settings, where alcohol and drugs are common and the social norms against deviant behaviour are weak (Hirschi 1969). Unemployment affects crime more during weekdays than at weekends (Rege et al. 2009; Grönqvist 2011), which indicates that idleness is a crime-related element.

Most studies investigate the crime reducing effect from secondary education, but to my knowledge, few studies investigate the crime reducing effect from tertiary education. An explanation is that tertiary students are not assumed to be predisposed to crime, and studying the preventative effect of tertiary education is therefore of little interest. Another explanation is that the marginal and average student differ in their propensity to commit crime, and few studies are able to identify the tertiary crime reducing effect for the marginal student. However, according to statistics from the 1980 wave of the National Longitudinal Survey of Youth (NLSY) neither the first nor the second explanation seem to be correct. It is reported that $17 \%$ of the men with a tertiary education self-report some income from crime (Lochner 2004, 2010). The NLSY also indicates that investments in tertiary education are associated with a substantial reduction in crime. A recent study by Baker and Lang (2013) support the finding that individuals in the middle of the educational distribution are, indeed, on the margin of crime. They find that high school exit examswhich reduce graduation rates - are associated with a $12.5 \%$ increase in incarceration. US exit exams are assumed to affect a similar margin as the margin in this study: relatively low performing students in high school (US) and upper secondary education (Sweden).

\section{Grade Inflation and the Tertiary Education System}

\section{Grade Inflation}

With the introduction of the goal-and criterion-referenced grading system in 1994, grades among school-leavers in Sweden started to increase. The first cohort with the new grades graduated in 1997, but since data is available from 1998 and onwards the study period in this paper is 1998-2010. Between 1998 and 2004, the average grade (meritvärde) increased by about 0.25 standard deviations (Gustafsson and Yang Hansen 2009) and frequency of students with the maximum grade increased from less than $0.1 \%$ to about $1 \%$ (Vlachos 2010). Figure 1 shows the change in grades (averaged over municipalities) for the period for which municipal data are available (1998-2010). However, a similar increase in knowledge has not been found (Cliffordson 2004; Gustafsson and Yang Hansen 2009; Björklund et al. 2010), and international tests such as PISA, TIMSS and PIRLS actually report a decrease in maths, science and reading ability (Skolverket 2012). Thus the consensus is that the increase is due to grade inflation. The grades stopped increasing after 2003, probably due to general awareness of the phenomenon, which culminated in the inspection by the Swedish National Audit Office in 2004.

Grade inflation also increased the proportion of upper-secondary school students who were eligible for tertiary education by more than 6\% points between 1998 and 2003, as illustrated in Fig. 1. To obtain a certificate providing eligibility for tertiary education, 


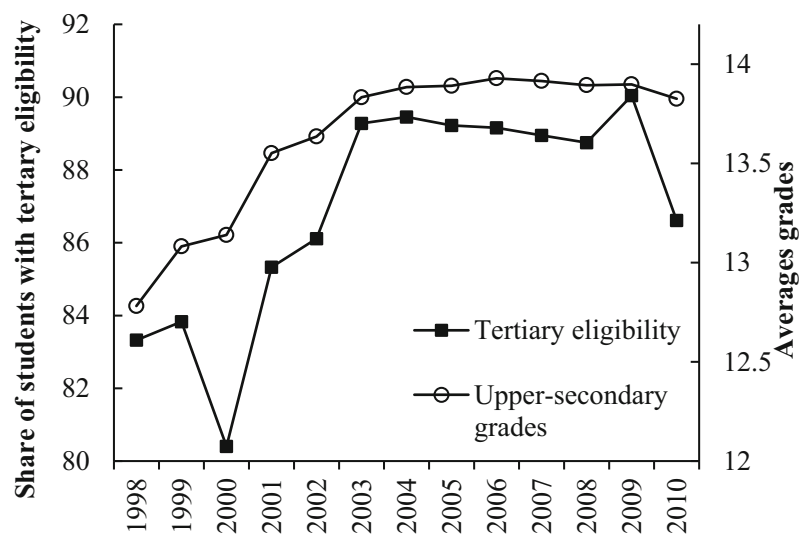

Fig. 1 Proportion of students with tertiary education eligibility and change in grades (averaged over municipalities), 1998-2010

students must achieve pass grades in $90 \%$ of their courses. ${ }^{1}$ Figure 2 shows the large variation in the magnitude of the increase in tertiary education eligibility (between 1998 and 2003) between municipalities, with some municipalities having a decrease in the eligibility rate. For $85 \%$ of the municipalities, the change in tertiary eligibility between 1998 and 2003 is positive.

Although the introduction of the new grading system made grade inflation possible (substantial grade inflation could not exist in the former relative grade system where grades were intended to follow a normal distribution on a national level), increased school competition is probably the driving factor (Wikström and Wikström 2005). From the academic year 1992-1993 on, all Swedish students have the right to choose a school outside their local catchment area and the student funding moves with the student. This school reform has had an effect on school competition and the number of private schools in Sweden has increased dramatically. In upper-secondary education, the number of private school increased by almost 200\% between 2001 and 2009, and the share of students choosing a private school increased from 2 to about 20\% in 2009 (Skolverket 2012). However, according to Vlachos (2010), school competition is a general phenomenon, and private schools are only responsible for a minor part of the grade inflation. Also, sensitivity test shows that the relationship between tertiary education eligibility and crime is not caused by the increase in private schools.

The increase in tertiary education eligibility has not attracted public attention. The main reason for the lack of attention is that research has focused on grade inflation in compulsory schooling, and upper-secondary school eligibility has actually decreased during the period.

Decreasing the basic eligibility requirements mainly affects the lower part of the skill distribution and makes tertiary education available to young people at the margin of eligibility; without grade inflation, they would not have the opportunity to attend tertiary

\footnotetext{
1 The drop in the tertiary eligibility rate in 2000 was probably caused by new rules. From 2000 students had to attend and get a grade in all courses (i.e. at least a No Pass). Before 2000, for the courses without a pass grade the students did not even have to attend. However, the new rules had only a short-term influence on the tertiary education eligibility rate, which in 2001 was higher than in 1999. In 2010, the grading system changed again. Before 2010, there were four grade levels, but in 2010 the ECTS grading scale with six grade levels was introduced. This suppressed grades temporarily.
} 


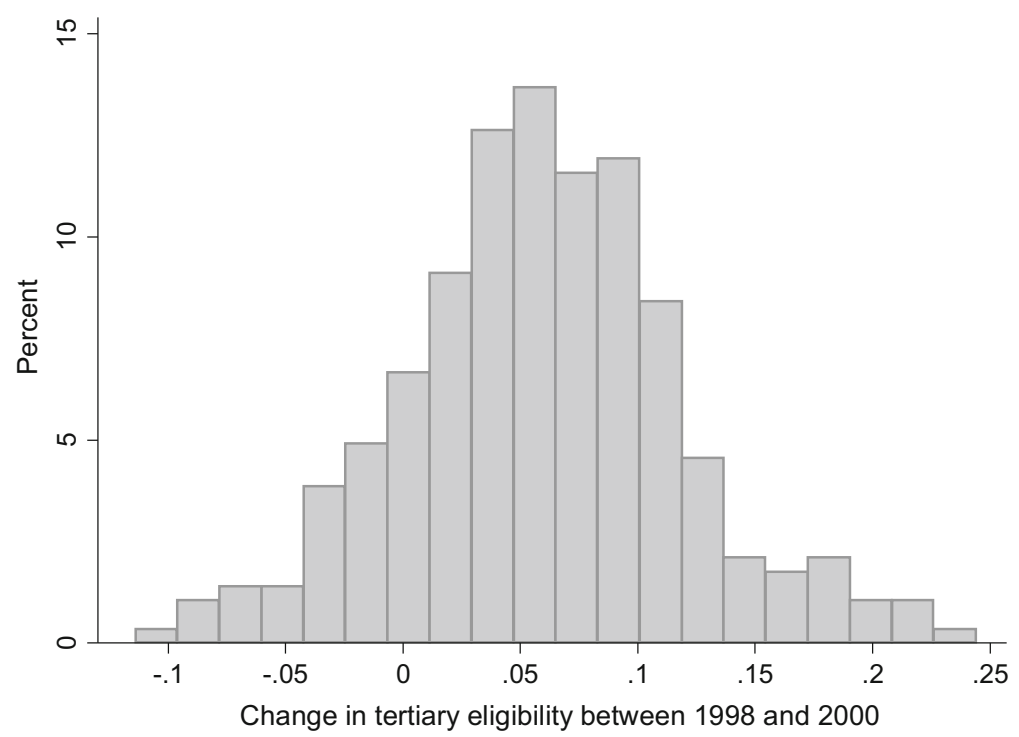

Fig. 2 Distribution of changes in tertiary education eligibility for Swedish municipalities, 1998-2003

education. At the time of finishing upper-secondary education the individuals at the margin of tertiary eligibility are around the 40th percentile of the educational distribution. ${ }^{2}$

Lowering the eligibility requirements may be beneficial, ${ }^{3}$ as higher education has a positive impact on the future working life of the eligible individuals. However, another positive effect is the focus in this study. Because the unemployment rate of low-skilled young people in Sweden is high, tertiary education may be a way for eligible individuals to avoid long-term unemployment and may reduce the negative externalities of unemployment.

\section{Tertiary Education and Study Places}

Tertiary education in Sweden is publicly administered and publicly funded. Studying in Sweden is always free of charge. In order to study at tertiary level, students are offered a grant and loans, with the grant making about up 30\% of the total. The number of student places in tertiary education is fixed, but occasionally colleges and universities accept more students than they are paid for. When the number of eligible applicants exceeds the number of places available, there are two ranking systems to decide place allocation. The applicants are separately ranked according to their average upper-secondary grades and their score in an optional scholastic aptitude test. Almost 30\% of those accepted into tertiary education are accepted on the basis of the scholastic aptitude test.

If more student places than eligible applicants are available, every eligible student will have the opportunity to attend tertiary education. At the beginning of the 1990s the number of student places began to increase, and between 1998 and 2003 it increased by about $22 \%$.

\footnotetext{
${ }^{2}$ About $30 \%$ of a cohort are dropouts of finish upper secondary education and about $10(70 \times 15)$ percent fail tertiary eligibility.

${ }^{3}$ However, grade inflation is mainly negative as it reduces the informative signal and legitimacy of grades and creates inequality between cohorts and individuals.
} 
Fig. 3 Number of student places at tertiary education establishments in relation to total number of young people aged $19-25$

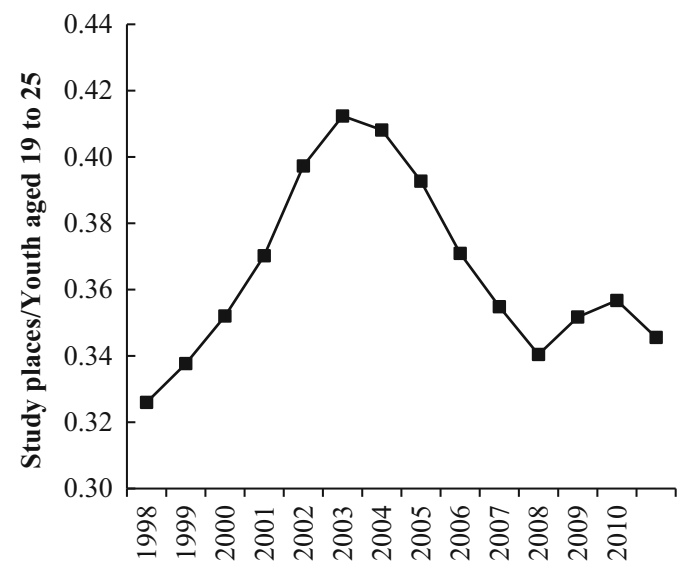

Figure 3 shows that the change in number of student places relative to the total number of young people (aged between 19 and 25) was even larger, 26\%, because of a decrease in the latter. ${ }^{4}$ Between 2003 and 2010, the number of student places fluctuated slightly (decreased between 2003 and 2008 and increased between 2008 and 2010), but a large increase in the total number of young people in Sweden meant that the number of student places per young person decreased by $13.5 \%$. Hence, between 1998 and 2003 the probability of being accepted into tertiary education increased for individuals at the margin of tertiary eligibility, while after 2003 the probability decreased.

\section{Data}

The panel data set consists of annual data for $287^{5}$ municipalities over the period 1998-2010. With some missing values, the total is 3687 observations. The Swedish National Agency for Education (Skolverket) is the source of most of the education data, e.g. grades, student population and the share finishing upper-secondary education. However, the eligibility for tertiary education measure is taken from Statistics Sweden, since they report this variable for a longer period than the Swedish National Agency for Education. Data on the numbers of first-year students in tertiary education in each municipality are taken from the Swedish Higher Education Authority (Högskoleverket).

Eligibility for tertiary education is measured at the municipality level, and it is calculated as the ratio between the number of school leavers eligible for tertiary education in year $t$ and the total number of students leaving school in year $t$. As already mentioned, to receive a certificate proving eligibility for tertiary education, students must achieve pass grades in $90 \%$ of their courses. However, school leaving is not based on educational performance, but simply on finishing 3 years of upper-secondary education.

The Swedish Higher Education Authority collects data on the number of first-year students in tertiary education. The data are based on municipality of residence in the year

\footnotetext{
${ }^{4}$ Calculated here using cohort data and data on the yearly numbers of individuals in tertiary education obtained from Statistics Sweden.

5 Sweden contains 290 municipalities, but Nykvarn and Knivsta were created during the period and are therefore excluded. For Bjurholm, most education data are lacking.
} 
before beginning tertiary education, and therefore indicate the number of individuals in each municipality beginning tertiary education. By calculating the ratio between the number of first-year students and the student population finishing upper-secondary education, we obtain a proxy ${ }^{6}$ of the proportion of upper-secondary students beginning tertiary education. Using this variable as the dependent variable, we can analyse whether the marginal change in tertiary eligibility affects the proportion of students beginning tertiary education.

Data on crime rates are provided by The National Council for Crime Prevention (NCCP), and they are reported as crimes per 100,000 inhabitants. Here we divide the crimes into property crimes and violent crimes, but we also analyse specific crime categories. The crime rate has increased by 10-20\% since 1985, as shown in Fig. 4. Property crime includes burglary, thefts and pilfering, thefts from vehicles and handling stolen property. ${ }^{7}$ For violent crimes, the categorisation we use here follows that of NCCP with one exception: robbery is excluded from violent crimes (except when analysing the specific crime categories separately; see Appendix Table 6). The reason is that the motive for robbery is mostly monetary, while in the present analysis we want to focus on 'pure' violent and property crime categories.

Figure 4 also illustrates separately the change in the property crime rate and the violent crime rate. For property crimes, there has been a steady decrease in crime rates during the last decade and they have decreased by about $30 \%$ since 2000 . An entirely different trend is seen for violent crimes, which have gradually increased over a long time and rose by more than $40 \%$ from 1998 to 2010 . However, it has been shown that a higher reporting rate explains the increase in reported violent crimes (NCCP 2008).

\section{Econometric Specification}

The main difficulty in identifying the educational attainment effect on crime is the endogeneity of choices; the same characteristics that determine the achievement in school may also determine the choice between legal and illegal activities (Lochner and Moretti 2004). Theoretically, because schooling determines the utility of legal activities, the schooling investment decision has to be considered when individuals evaluate the expected utility of legal and illegal activities and choose that with the highest payoff (Becker 1968). The endogeneity of school and crime may therefore bias the effect of educational attainment on crime if the education investment and crime decision occur simultaneously. Moreover, criminal activity may precede and cause weak school achievement, which means reverse causation.

With aggregate data, cohort differentials in characteristics may bias the tertiary education eligibility effect, so that some student cohorts are more inclined to choose criminal activities over non-criminal activities (e.g. schooling). Factors that could create cohort differentials include changes in inequality, parents' educational level, immigrant composition or school resources.

\footnotetext{
${ }^{6}$ Because the tertiary beginner variable includes all beginners and not only newly graduated beginners, the measure is an imperfect measure of the share of tertiary beginners among newly graduated students.

7 We exclude Vehicle Thefts. Due to technological advances, cars are difficult to steal today, and with a $60 \%$ drop in vehicle thefts since the beginning of the $90 \mathrm{~s}$ (NCCP 2008) this crime category is difficult to analyse. The results in this paper are, however, not affected by excluding autothefts.
} 
Fig. 4 Change in log.points of different types of crimes, 1985-2010

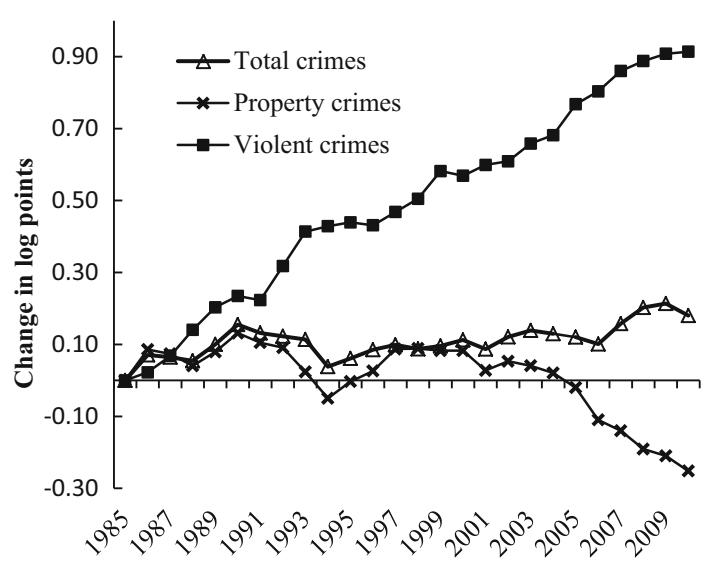

Hence, to estimate an unbiased educational attainment effect on crime, the change in educational attainment has to be exogenous. Because grade inflation increases measured achievement in school, and thus the proportion with tertiary education eligibility (as illustrated in Fig. 1), we can exploit this variation to estimate a causal effect of tertiary education eligibility on crime.

The model specification presented in Eq. (1) is the standard when using aggregate panel data. Using a fixed effect model with a full set of time and municipality dummies, we can estimate the effect of the within-municipality variation in eligibility for tertiary education on crime as:

$$
\text { LnCrime }_{i t}=\alpha_{i}+\delta_{t}+\beta_{98-03} \text { Elig }_{i t} \times T_{98-03}+\beta_{04-10} \text { Elig }_{i t} \times T_{04-10}+\rho X_{i t}+\varepsilon_{i t} .
$$

where $\alpha_{i}$ represents unobservable municipality characteristics that are constant over time, and $\delta_{t}$ is time-fixed effects. The tertiary education eligibility rate is interacted with two dummy variables, $T_{98-03}$, and $T_{04-10}$, for the periods $1998-2003$ and 2004-2010, respectively. The tertiary education eligibility effect $\beta_{98-03}$ is for the grade inflation period and the tertiary eligibility effect $\beta_{04-10}$ is for the non-grade inflation period. $X$ represents additional covariates. The standard errors are clustered on municipal level a weighted with municipality population size. In causal analysis, ${ }^{8}$ Solon et al. (2015) recommend weighting if heteroscedasticity is an issue. A Breusch-Pagan test (Wooldridge 2013) indicates heteroscedasticity in our data, so the estimates are more precisely estimated using a weighted model.

We can apply this model to evaluate whether a higher rate of tertiary education eligibility during the grade inflation period decreases crime. To conclude that the tertiary education eligibility effect is causal and runs through tertiary attendance, here we examine whether: (1) the tertiary education eligibility effect vanishes when young people on the margin of tertiary eligibility have a lower probability of being accepted into higher education, and (2) other variation in tertiary education eligibility (e.g. changes in scholastic achievements) may be causing the effect.

Demonstrating that the tertiary education eligibility effect runs through tertiary attendance, we show a positive association between tertiary education eligibility and tertiary attendance during the grade inflation period. However, after the period of grade inflation,

${ }^{8}$ In descriptive analysis, weighting makes the sample representative of the target population (Solon et al. 2015). 
tertiary education eligibility does not affect tertiary attendance. Plausibly, those at the margin of tertiary eligibility are less likely to be accepted into tertiary education due to fewer study places.

Regarding the effects of other variation, although the inflation in eligibility is exogenous, our specification does not separate the exogenous variation from other variation in tertiary eligibility (e.g. changes in scholastic abilities). The problem is therefore not whether we have exogenous variation in the independent variable, but rather whether we can trace out the exogenous part. Nevertheless, because the effect is exceptionally robust to the inclusion of covariates (even upper-secondary school grades, a control that captures most of the variation in cohort scholastic ability) we are confident that the majority of the tertiary education eligibility effect in crime relies on the exogenous inflation in student eligibility. Besides, if the change in tertiary eligibility is not entirely exogenous, and partly caused by e.g. improved upper-secondary school quality, the results in this study are still relevant.

\section{Additional Control Variables}

Any student completing 3 years of upper-secondary education and getting a final grade is classified as finishing upper-secondary education. However, that student may still fail to achieve tertiary education eligibility, i.e. by getting pass grades for more than $90 \%$ of courses. By controlling for the proportion of students finishing upper-secondary school, it can be seen that the tertiary education eligibility effect is not caused by a change in the denominator of the eligibility ratio between students eligible for tertiary education and students finishing upper-secondary school. Without controlling for the proportion finishing upper-secondary school, the tertiary eligibility effect on crime may be caused by selection in the sample of students finishing upper-secondary school. In other words, if the uppersecondary school dropout rate increases, the population finishing upper-secondary school may become more selective and more likely to attain tertiary education eligibility. In that case, the increased tertiary education eligibility rate may be related to the dropout rate rather than grade inflation. ${ }^{9}$ The size of the nineteen age cohort (divided by the total population) is also included, as otherwise crime rates may be affected by a lost uppersecondary school incapacitation effect.

We finally include a set of demographic controls in the main specification. The demographic covariates are Proportion of men, Proportion with foreign background (including both first- and second-generation immigrants), Inflow and Outflow (number of people entering and leaving of the municipality divided by municipal population size), Logarithmic population size and the demographic age structure.

In the sensitivity analysis we also add socioeconomic covariates, alcohol consumption and additional school characteristics (e.g. grades). These are not included in the main specification due either to their endogenous character or missing variables. Table 5 lists all the variables used in this study and reports some descriptive statistics.

\footnotetext{
${ }^{9}$ We also tried computing the share eligible for tertiary education in relation to the entire cohort, but this metric captures both variations in the proportion finishing upper-secondary school and variations in the proportion with tertiary education eligibility. Thus, the estimated effect includes the dropout effect on crime, which is entirely different from the true tertiary education eligibility effect, which we isolate through the grade inflation in the tertiary eligibility rate.
} 


\section{Results}

We begin by reporting the main results of the study, followed by the results from a TSLS model, where we show that the tertiary education eligibility effect on crime is linked to tertiary attendance. Finally, additional controls and municipality-specific time trends are included in the model.

\section{Main Results}

Table 1 presents result when estimating Eq. (1) for property and violent crimes, respectively. Column (1) shows the results obtained for property crime without covariates included in the model, while column (2) shows the results with covariates included. Columns (3) and (4) show the corresponding results for violent crime. The tertiary eligibility is assumed to run through tertiary attendance. For comparability we estimate in columns (5) and (6) the overall relationship between tertiary attendance and violent crime and property crime, respectively. With a variable measuring the proportion of students beginning tertiary education the tertiary attendance effect is captured.

During the grade inflation period, increasing the tertiary education eligibility rate by $1 \%$ point decreases property crimes by around $0.35 \%$ points. Comparing columns (1) and (2) shows that the effect is the same with and without covariates. For violent crime, the tertiary eligibility is 0.50 without covariates (column 3 ) included and 0.34 with covariates (column 4). We have also estimated the eligibility effect for municipalities with a decrease in tertiary eligibility between 1998 and 2003 separately, and found the same result (not reported), i.e. when tertiary eligibility decreases crimes increases. Thus, when the requirements for reaching eligibility are changed, students who would otherwise not be eligible for tertiary education commit less crime. The unemployment rate, which is based on changes in the unemployment rate of the entire population, increases property crime by around 1-2\% (Lin 2008; Mustard 2010), and therefore a tertiary eligibility effect, which is based on changes in eligibility for one single cohort, of 0.3 or higher is a very large effect.

Columns (5) and (6) show that tertiary attendance affects both crime categories for the period 1998-2003 and violent crime for 2004-2010. The tertiary attendance effects for 1998-2003 are about one third of the tertiary eligibility effect.

However, a problem with our specification is that the tertiary eligibility measure is a flow variable but tertiary attendance is a stock variable. It implies that an increase in the tertiary eligibility rate (assumed to increase the inflow into tertiary education) affects crime for several years. For example, if the mean years of tertiary enrolment is 3 years (i.e. a bachelor degree), an increased inflow with one student implies an increased long-run stock of students with three. An increasing tertiary eligibility rate therefore identifies a change in the stock of student that is larger than the corresponding change in inflow. Thus, our tertiary eligibility effect is not identifying a cohort specific effect and to receive such effect we have to weight down the effect with the long-run change in the stock of students. However, since we do not know the average enrolment time for the marginal student and whether the (assumed) tertiary attendance effect is constant during the enrolment period, it is difficult to do this calculation. As an alternative exercise, we test if the impact changes when restricting the change in the stock, i.e. by restricting the sample period the grade inflated change in the stock of students has not gained full effect.

Thus, if we restrict the sample period to 1998-2001 only one cohort is substantially affected by the increased tertiary eligibility rate (see Fig. 1). For this period (not reported) 


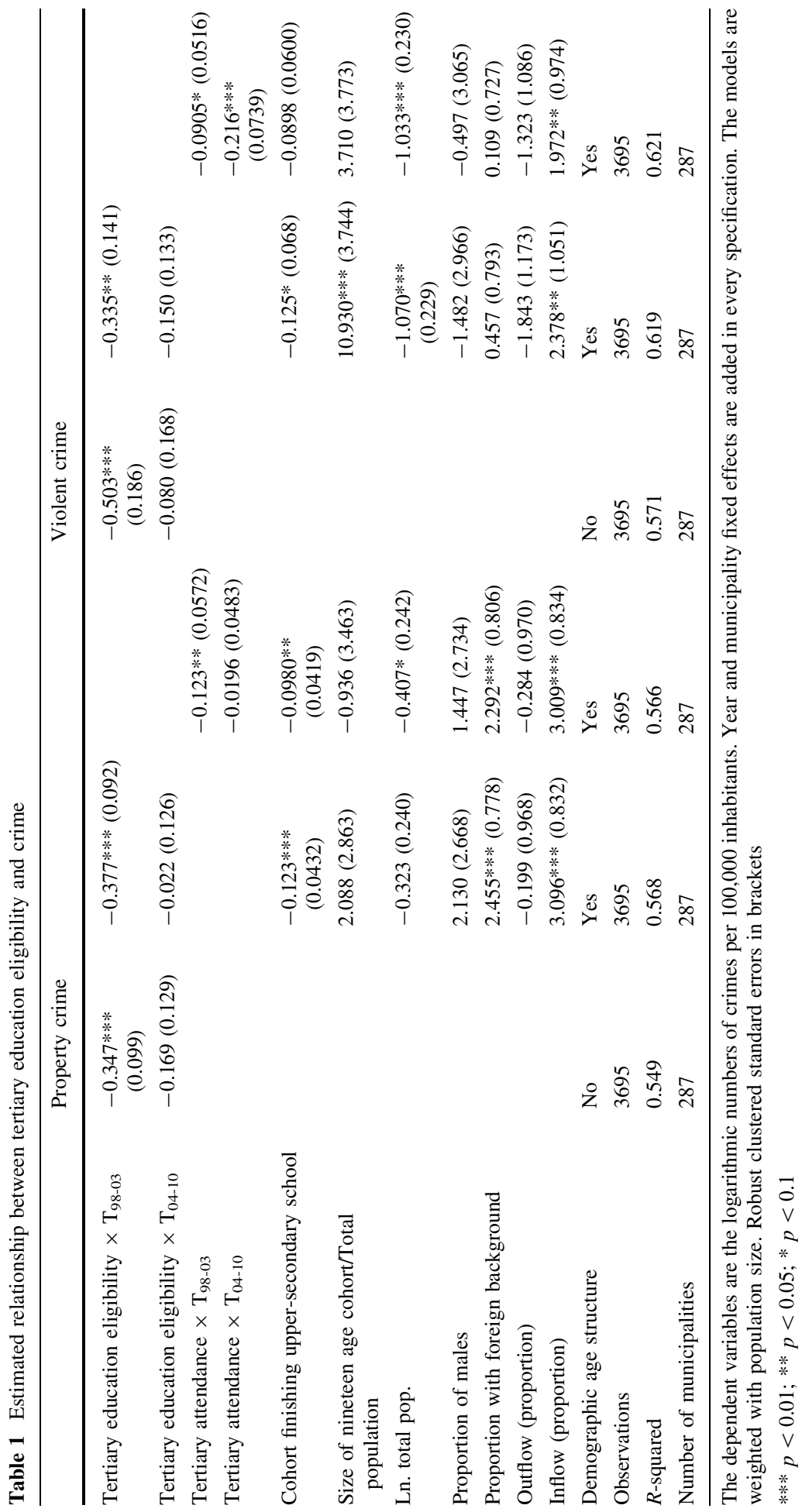


we find that the tertiary eligibility effects are significant and about a third, -.12 for property crime and -.13 for violent crime, of the effects in Table 1. However, this may still seem as a large estimate, but the targeted population, the nineteen age cohort, is heavily overrepresented as offenders: according to Hansen (2003) and Swedish official statistics $10 \%$ of all offenders are aged nineteen.

To assess the size of the effects we use this number and the tertiary effects for the restricted sample to calculate the overall reduction in crimes for the nineteen age cohort. We find that a $1 \%$ increase in the tertiary eligibility rate corresponds to a decrease in crimes committed by the nineteen age cohort of 1.2 and $1.3 \%$ for property and violent crime, respectively. A similar large effect is found in Åslund et al. (2012), who find that the incapacitation effect of a third year of vocational upper-secondary schooling decreased the conviction rate by $20 \%$ for the cohort attending the third year. The results show that changing the criminal behaviour in peak criminal ages has a huge impact on crime.

For the post-inflation period, it can be seen that the tertiary education eligibility effect is insignificant. ${ }^{10}$ This finding indicates that marginal changes in tertiary education eligibility caused by variation in the educational achievements of cohorts alone do not affect crimes. As previously discussed, and shown in the next section, to have an impact on crime the marginal student (affected by the change in tertiary education eligibility requirements) also has to choose to invest in tertiary education.

As columns (2) and (4) of Table 1 show, an increasing proportion of students finishing upper-secondary education has a negative effect on property crimes. However, since finishing upper-secondary school is merely about completing education, and not grades, the proportion finishing upper-secondary school is not inflated. Thus, this indicates a different mechanism.

By including a lagged tertiary eligibility variable to the model, we have also analyzed whether the tertiary eligibility effect remains (not reported). We find that tertiary eligibility reduces crime the year after graduating from upper secondary education, but the impact is smaller. In the next year, the second after graduation, the effect is small and insignificant.

With the data available, it is also possible to investigate the tertiary education eligibility effect on particular crimes types, as shown in Table 6. During the grade inflation period, significantly negative tertiary education eligibility effects on burglary, theft and pilfering, theft from vehicles, assault and rape can be seen. Because university studies may enable drug and alcohol use, this may explain why there is no negative effect on alcohol and narcotics crimes. For some uncertain reason, a positive effect on handling stolen property can be seen for the period 2004-2010.

\section{Investigating the Mechanism Behind the Tertiary Eligibility Effect on Crime}

To establish that the tertiary eligibility effect on crime is caused by a voluntary attendance effect of tertiary education, we go on to explore the association between the eligibility rate and the proportion of students beginning tertiary education. For this, we can test whether the tertiary eligibility effect on crime is caused by increased investment in education by individuals at the margin of eligibility using a TSLS model. Causal inference is achieved if the change in tertiary eligibility is exogenous. As discussed previously, the grade-inflated

\footnotetext{
10 The insignificant tertiary education eligibility effects on crime for the post-inflation period are not caused by a lack of within-variation in the eligibility variable. Although the within-variation in eligibility is smaller during the post-inflation period (.032) than for the grade-inflation period (.048), it should be large enough to isolate an effect of tertiary eligibility on crime.
} 
variation in the tertiary eligibility measure is exogenous, but the measure also varies with scholastic achievement and cohort characteristics. However, the aim here is to show that the effect runs through tertiary attendance, not to provide evidence of a causal effect, i.e. even if the change in eligibility is not completely exogenous, marginal changes in eligibility have an impact on uptake of tertiary education.

Thus, the TSLS model identifies a tertiary attendance effect for individuals at the margin of tertiary eligibility. In comparison, the OLS models (in Table 1) estimate the tertiary eligibility effect and the tertiary attendance for the average student enrolling in tertiary education. ${ }^{11}$ The first-stage regression is:

$$
\text { Tert beg }{ }_{i t}=\alpha_{i}+\delta_{t}+\beta_{98-03} \text { Elig }_{i t} \times T_{98-03}+\beta_{04-10} \text { Elig }_{i t} \times T_{04-10}+\rho X_{i t}+\varepsilon_{i t}
$$

As in model (1), the tertiary education eligibility measure has separate effects during the grade inflation period (1998-2003) and the post-grade inflation period (2004-2010). Column (1) in Table 2 shows the first-stage regression results. As can be seen, during the grade inflation period, a $1 \%$ point increase in the tertiary education eligibility rate increases the proportion of students going to tertiary education by about $0.2 \%$ points. During the post-grade inflation period, tertiary eligibility has no impact on tertiary uptake. Thus, when the number of student places per young person decreases, the marginal individual is less likely to invest in higher education.

Thus, because tertiary eligibility does not affect tertiary uptake during the post-grade inflation period, the model is strengthened by removing the tertiary education eligibility variable for the post-grade inflation period. Column (2), which includes a tertiary eligibility measure for the grade inflation period alone, gives an increase in the weak-IV test. A weak instrument gives biased estimates and underestimated standard errors. A rule of thumb is that the F-statistic should be above 10, and the F-statistic in column (2) is 17.5. ${ }^{12}$

The second-stage regression effects on property and violent crimes are shown in columns (3)-(6) of Table 2, respectively. The TSLS estimates are larger than the OLS estimates given in Table 1 , around -1.5 to -2.0 for both crime types, and higher when only including the tertiary education eligibility measure for the grade inflation period. Thus, when identifying the marginal change in tertiary education attendance due to an inflated eligibility rate, there is a particularly high impact on crime. This can be expected, because TSLS identifies the marginal effect on crime [a continuous identification of a local average treatment effect (LATE)], i.e. for the proportion of students who actually take up tertiary education, while OLS identifies the average effect on crime, i.e. for the proportion of students who go on to tertiary education and for the proportion who do not. Thus while the first-stage results show an eligibility effect on tertiary education uptake of about 0.2 , the TSLS estimate is about five-fold higher (one in five students goes to tertiary education) than the OLS tertiary eligibility estimate. This result indicates that the positive impact of escaping a criminogenic setting through tertiary education is mainly important for the marginal pupil of receiving tertiary eligibility and not for the average student.

\footnotetext{
11 However, because the focus in this study is on variations in the tertiary education eligibility rate (the instrument in the TSLS model) rather than variations in the proportion of students beginning tertiary education (the independent variable in the TSLS model), we prefer the reduced form approach (i.e. OLS) to the TSLS approach.

12 The Kleibergen Paap statistic should be used when the standard errors are clustered (which is a heteroskedasticity robust generalization of the Cragg-Donald F-statistic). Since critical values have not yet been generated for the Kleibergen Paap statistic, critical values for the Cragg-Donald F-statistic [available in Stock and Yogo (2005)] is customary used.
} 


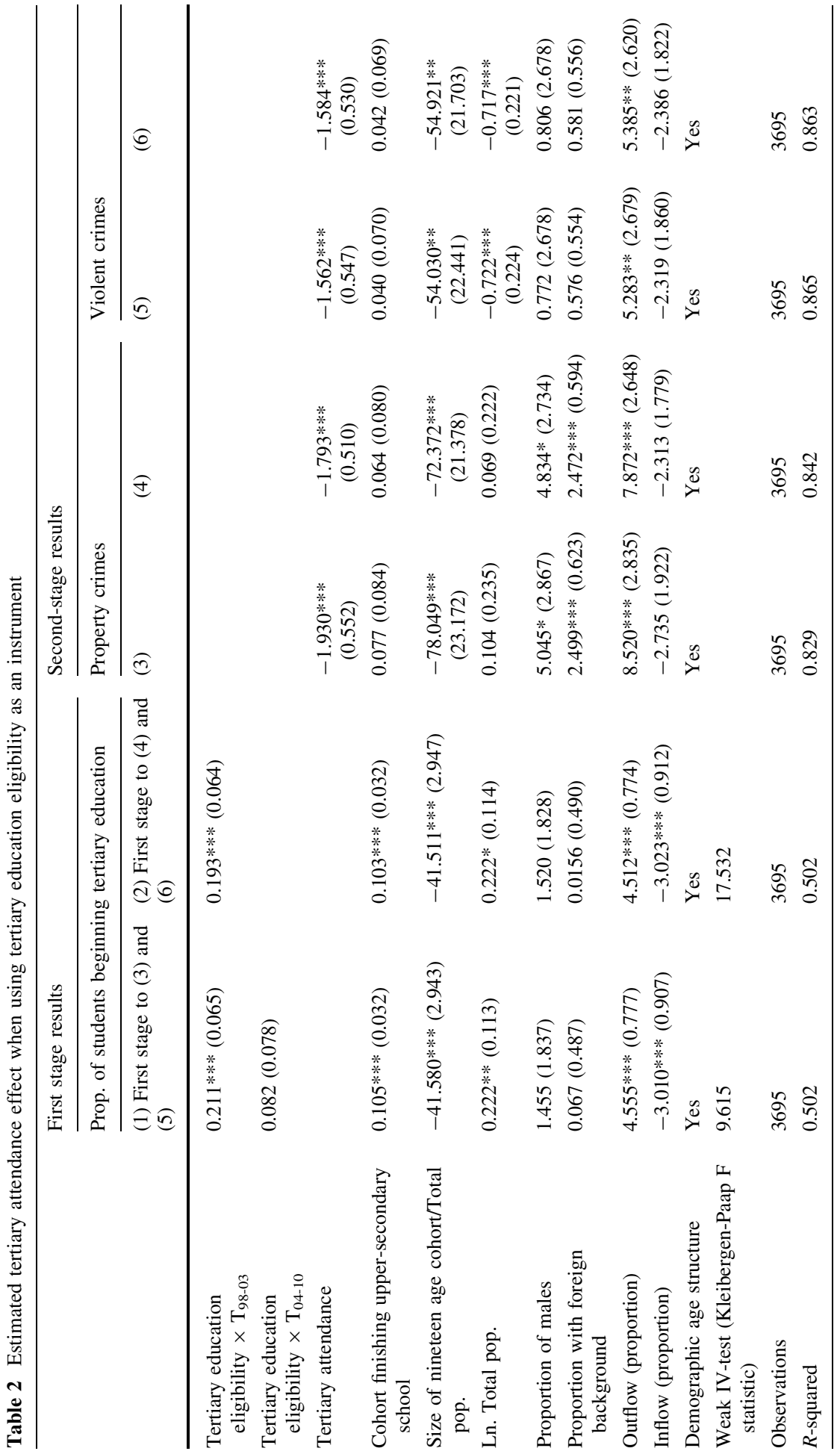




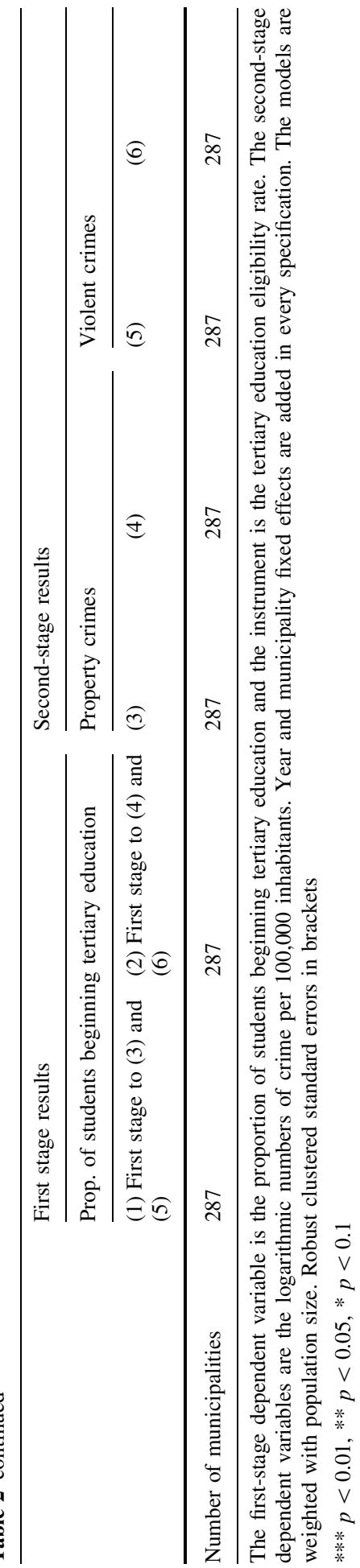


The conclusion is that the tertiary education eligibility effect on crimes is caused by young people investing in tertiary education. On also estimating the effect of tertiary education eligibility on youth unemployment (not reported), we find that it has no significant impact on the unemployment level, i.e. the impact on crime is through tertiary education attendance, and not changes in the youth unemployment rate. ${ }^{13}$

\section{Sensitivity Tests of the Tertiary Eligibility Effect}

In Table 3 additional controls are added to test the robustness of the tertiary education eligibility effect on crime. Columns (1) and (4) include income level, three different unemployment rates (total, long-term and youth) and three public cost measures (social, educational and cultural). Since alcohol consumption is known to affect crime rates and young people are known to drink heavily, an alcohol measure is also added in the model. These variables are not added to the baseline specification, due to their endogenous character, but their inclusion does not affect the tertiary education eligibility effects on crime (and the effects remain the same even when they are added step-wise).

The next step involves adding various school characteristics that might affect both the eligibility rate and the crime rate; the proportion of students attending a private school, the proportion of students with a foreign background and the average grades. Since there are many missing values for these variables, $27 \%$ of the sample is lost, but the sample change does not, in itself, affect the effect of eligibility for tertiary education (found when estimating the model for this sample, without adding the school characteristics). From column (2), for property crimes, and column (5), for violent crimes, we can see that school characteristics do not affect the eligibility effect of tertiary education and in fact adding them increases the effect for property crimes. The conclusion is that the tertiary education eligibility effect on crime is caused by grade inflation increasing the eligibility rate, and not cohort variation in scholastic ability.

Another interesting finding is that grades do not affect crime rates, a seemingly contradictory finding to the grade-inflated tertiary education eligibility effect on crime. A plausible explanation is that different margins change their further education plans when the eligibility requirements for tertiary education change and when the grades change. For example, individuals who respond to improved teaching or better school quality are probably less likely to commit crimes than individuals who gain eligibility for tertiary education due to arbitrary grade inflation. Educational outcomes at the compulsory level has been controlled for as well (the share finishing compulsory education, the share with upper-secondary eligibility and average grades for boys and girls, separately), and these do not affect the tertiary eligibility effect (result available on request).

The propensity to report a crime has changed over time and may also vary across Sweden over time (NCCP 2008). Linear time trends can be used to correct for such variation. Columns (3) and (6) in Table 3 show the results when adding linear time trends: the tertiary education eligibility effects on crimes decreases, but it stays large and significant. However, linear trends remove a large share of the variation in the dependent variable, and since the tertiary education eligibility effect is derived from a continuous increase in the eligibility rate, this test is likely to bias the effect downward. Hence, the

\footnotetext{
13 Note, when individuals go from unemployment to education both the nominator (unemployed individuals) and the denominator (the size of the labour force) of the unemployment ratio decreases, i.e. we mainly capture the pathway from unemployment to employment with this specification (then the nominator changes only).
} 


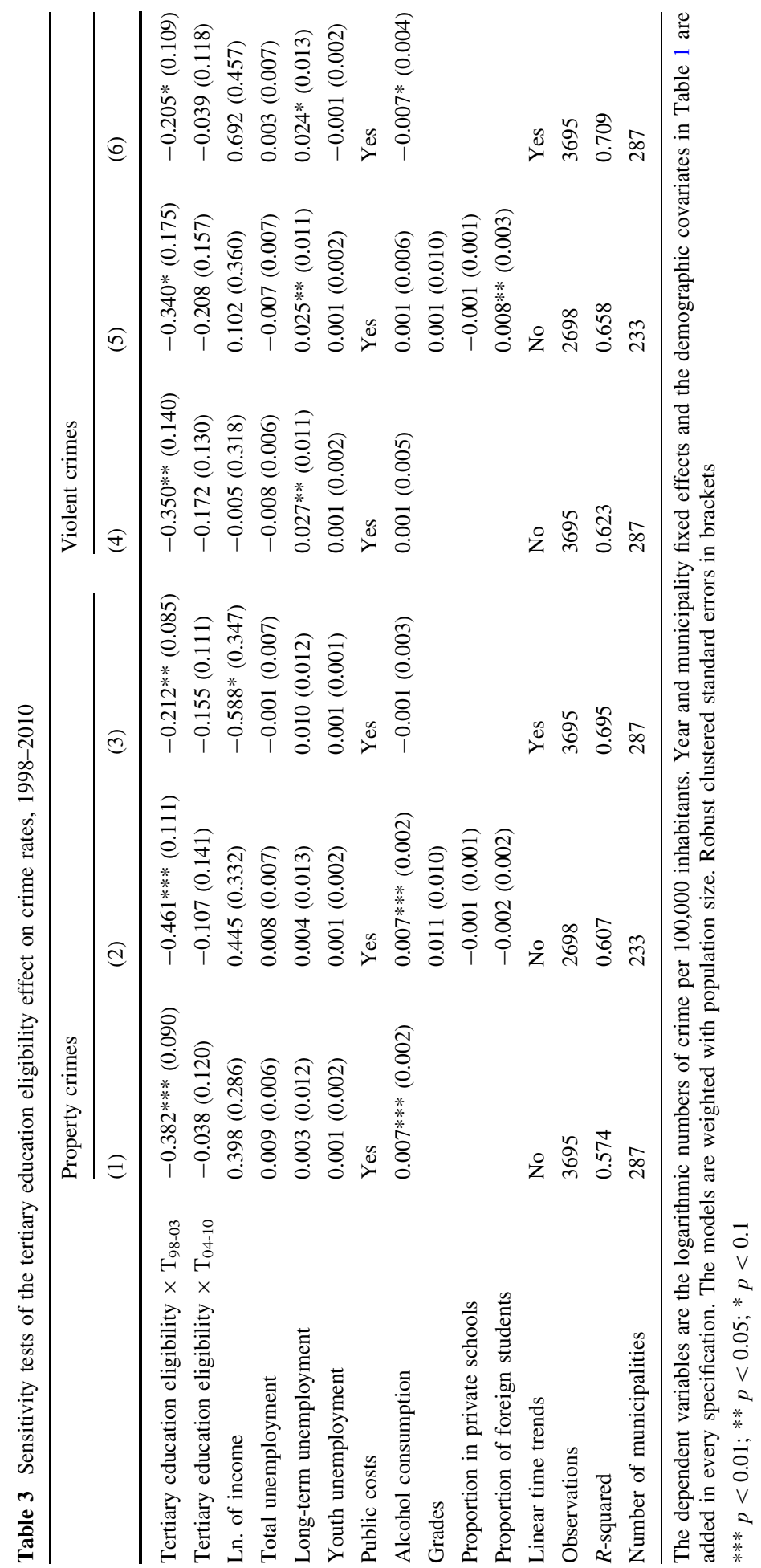


Table 4 Estimated relationship between tertiary education eligibility and crime rates for regions close to, or far from, a tertiary education establishment and for urban and rural regions

\begin{tabular}{|c|c|c|c|c|}
\hline & \multicolumn{2}{|l|}{ Year $\leq 2003$} & \multicolumn{2}{|l|}{ Year $\geq 2004$} \\
\hline & Property crimes & Violent crimes & $\begin{array}{l}\text { Property } \\
\text { crimes }\end{array}$ & Violent crimes \\
\hline \multicolumn{5}{|c|}{ Municipalities separated based on distance to university } \\
\hline $\begin{array}{l}\text { Tertiary education } \\
\text { eligibility in regions } \\
\text { close to a } \\
\text { university/college }\end{array}$ & $-0.495 * * *(0.116)$ & $-0.424 * *(0.183)$ & $-0.136(0.148)$ & $-0.233(0.161)$ \\
\hline $\begin{array}{l}\text { Tertiary education } \\
\text { eligibility in regions } \\
\text { far from a } \\
\text { university/college }\end{array}$ & $-0.236 * *(0.109)$ & $-0.239 *(0.134)$ & $0.125(0.131)$ & $-0.037(0.151)$ \\
\hline \multicolumn{5}{|c|}{ Municipalities separated based on urban/rural } \\
\hline $\begin{array}{l}\text { Tertiary education } \\
\text { eligibility in urban } \\
\text { areas }\end{array}$ & $-0.383^{* * *}(0.110)$ & $-0.297 *(0.162)$ & $-0.047(0.146)$ & $-0.162(0.150)$ \\
\hline $\begin{array}{l}\text { Tertiary education } \\
\text { eligibility in rural } \\
\text { areas }\end{array}$ & $-0.365 * * *(0.0954)$ & $-0.343 * * *(0.130)$ & $-0.017(0.124)$ & $-0.167(0.133)$ \\
\hline
\end{tabular}

The dependent variables are the logarithmic numbers of crime per 100,000 inhabitants. Year and municipality fixed effects, the proportion of students finishing upper-secondary education, the student population and the demographic covariates in Table 1 are added in every specification. The models are weighted with population size. Robust clustered standard errors in brackets

$* * * p<0.01 ; * * p<0.05 ; * p<0.1$

finding of a tertiary education eligibility effect on crimes with time trends included strongly indicates that the effect of tertiary education eligibility on crime is not a spurious finding. We have also controlled for the conviction rate and the size of the police force. The tertiary eligibility effects decrease with around 5\% with these variables included, but due to endogeneity concerns we prefer not to control for these factors.

\section{Does the Distance to a University Affect the Tertiary Education Eligibility Effect on Crime?}

All other things being equal, high marginal costs of education decrease the probability of an individual investing in higher education. The marginal individuals who become eligible for tertiary education due to grade inflation may be particularly sensitive to the costs of education, since their marginal return on schooling is expected to be low on average. That is, since this group belongs to the lower end of the upper-secondary grade distribution, their scholastic ability, which determines their marginal return on schooling (Card 1999), is presumably low.

Although the financial costs of education are low in Sweden, moving and commuting costs, and the emotional cost of leaving family and friends, may have a large impact on the education investment decision of the marginal group. Thus, greater distance from a university or college may reduce the probability of those becoming eligible for tertiary education due to grade inflation investing in tertiary education. Moreover, in regions without a university, the norms may not favour tertiary education. If this hypothesis is 
correct, the tertiary education eligibility effect on crime is smaller in regions far from a university/college. Thus inflation in the tertiary education eligibility rate has no impact on crime rates if young people choose not to escape from inactivity or unemployment, even if they have the option.

To test this hypothesis, the sample of municipalities can be divided into two groups; (1) those which have a university in their own or are a neighbouring municipality (176 municipalities), and (2) those which do not (111 municipalities). For each of the groups, two separate tertiary eligibility variables are added to the specification (one for each time period: $\leq 2003$ and $\geq 2004$ ). In the upper panel of Table 4 , the tertiary education eligibility effects on crime are shown for these two groups (columns (1) and (2) show $\leq 2003$, and columns (3) and (4) 22004). As expected, the tertiary education eligibility effects are larger in municipalities with, or close to, a university/college than in municipalities far from a university/college. ${ }^{14}$

However, as the municipalities far from a university or a university/college are also more rural and the relationship between crime and education might differ between urban and rural areas, we have to divide the groups into rural and urban regions based on the median population density. A separate model is needed to estimate the tertiary education eligibility effect for these groups. The lower panel of Table 4 shows the results: the tertiary education eligibility effect is almost the same in urban and rural areas, which demonstrates that distance from a university, but not rurality, is important. This comparison of effects shows results that are consistent with education being a way of escaping inactivity and idleness, and also shows that the cost of higher education matters.

\section{Conclusions}

In this paper we offer a new understanding of how the education system affects crime rates. The underlying concept is that continuing to tertiary education is a way of escaping youth inactivity and idleness and, since youth inactivity is known to trigger crime, the voluntary attendance effect of tertiary education decreases the individual's probability of committing crime. However, young people with a high probability of deviant behaviour are also likely to have poor upper-secondary school grades and may therefore lack tertiary education eligibility. Thus young people with the largest potential benefit from escaping a criminogenic setting through tertiary education often lack the main tool, tertiary eligibility. Hence, it is relevant to investigate whether an increased tertiary education eligibility rate decreases crime rates.

To identify the tertiary education eligibility effect on crime, this paper uses a variation in tertiary eligibility arising from substantial grade inflation in Sweden in a particular period. Because inflation in the eligibility rate is exogenous to the educational attainments of a student cohort, we argue that the tertiary eligibility effect is causal. We demonstrate a negative tertiary education eligibility effect on property and violent crimes, but these effects disappear when the number of student places at tertiary education establishments decreases, i.e. when the marginal individual is less likely to be accepted into tertiary education.

\footnotetext{
14 Notably, the difference in estimates between the municipality groups is not produced by a small withinvariation in the tertiary eligibility rate for municipalities far from a university/college. In fact, the withinvariation is actually larger for group (1) municipalities (0.053) than for group (2) municipalities (0.045).
} 
Compared to other studies on incapacitation/attendance effects who find no, or even a positive, impact on violent crimes, we find that tertiary attendance reduce violent crimes. It has been suggested that social interactions at school increase the likelihood of violent conflicts (Jacob and Lefgren 2003), and that the peer group at school is an important determinant for crime (Deming 2011). However, earlier studies investigate peer effects at lower levels of education, and peer influences at the tertiary education level are more likely to have a constraining effect on deviant behaviour. Hence, differences in peer groups may explain why we receive a different effect on violent crimes compared to other studies on incapacitation/attendance effects, i.e. individual attending tertiary education changes to a better peer group. The effect in this paper may also be caused by fewer potential victims of crime. The explanation is that students congregate in certain areas (e.g. certain student bars in certain areas) so that offenders and victims are separated in space.

The apparent implication is that policies aimed at increasing the proportion of young people eligible for tertiary education through improved scholastic achievement are important, as they reduce crime rates. However, the main implication is that the same outcome can be obtained by lowering the eligibility requirements, so that fewer young people are trapped in long-term unemployment and inactivity.

This study questions the common assumption that individuals at the margin of tertiary education are not predisposed to crime. There is a consensus that compulsory- and secondary education have a substantial impact on crime, but few studies have examined the impact of tertiary education. A shortcoming is that we use aggregate (municipality) crime data on the population level. The result would be more reliable if we could have used aggregate crime data for youth or - even better-individual arrest data. With this in mind, the novel result and the high-level of data aggregation, the results have to be interpreted with caution. On the other hand, the results call for more research on the relationship between higher education and crime.

Open Access This article is distributed under the terms of the Creative Commons Attribution 4.0 International License (http://creativecommons.org/licenses/by/4.0/), which permits unrestricted use, distribution, and reproduction in any medium, provided you give appropriate credit to the original author(s) and the source, provide a link to the Creative Commons license, and indicate if changes were made.

\section{Appendix}

See Tables 5 and 6.

Table 5 Descriptive statistics

\begin{tabular}{lllllll}
\hline & Mean & $\begin{array}{l}\text { Std. } \\
\text { Err. }\end{array}$ & Between & Within & N & Source \\
\hline $\begin{array}{c}\text { Ln Property crimes (per } \\
\text { 100,000 population) }\end{array}$ & 8.196 & 0.359 & 0.299 & 0.198 & 3696 & $\begin{array}{c}\text { The National Council for } \\
\text { Crime Prevention }\end{array}$ \\
$\begin{array}{c}\text { Ln Violent crimes (per } \\
\text { 100,000 population) }\end{array}$ & 6.416 & 0.462 & 0.360 & 0.290 & 3696 & $\begin{array}{c}\text { The National Council for } \\
\text { Crime Prevention }\end{array}$ \\
$\begin{array}{c}\text { Tertiary education eligibility } \\
\text { Finishing upper-secondary } \\
\text { education }\end{array}$ & 0.870 & 0.058 & 0.033 & 0.048 & 3687 & $\begin{array}{c}\text { Statistics Sweden } \\
\text { The Swedish National } \\
\text { Agency for Education }\end{array}$ \\
$\begin{array}{c}\text { Size of nineteen age } \\
\text { cohort/total population }\end{array}$ & 0.013 & 0.002 & 0.001 & 0.001 & 3695 & $\begin{array}{c}\text { The Swedish National } \\
\text { Agency for Education }\end{array}$ \\
$\begin{array}{c}\text { Tertiary beginners(student } \\
\text { population) }\end{array}$ & 0.548 & 0.162 & 0.132 & 0.094 & 3695 & $\begin{array}{c}\text { Swedish Higher Education } \\
\text { Authority }\end{array}$ \\
\hline
\end{tabular}


Table 5 continued

\begin{tabular}{|c|c|c|c|c|c|c|}
\hline & Mean & $\begin{array}{l}\text { Std. } \\
\text { Err. }\end{array}$ & Between & Within & $\mathrm{N}$ & Source \\
\hline Ln. Total pop. & 9.840 & 0.903 & 0.907 & 0.030 & 3696 & Statistics Sweden \\
\hline Proportion of males $(\%)$ & 0.501 & 0.008 & 0.007 & 0.002 & 3696 & Statistics Sweden \\
\hline $\begin{array}{l}\text { Proportion with a foreign } \\
\text { background }(\%)\end{array}$ & 0.115 & 0.070 & 0.069 & 0.014 & 3696 & Statistics Sweden \\
\hline Outflow (proportion) & 0.048 & 0.012 & 0.011 & 0.004 & 3696 & Statistics Sweden \\
\hline Inflow (proportion) & 0.049 & 0.014 & 0.013 & 0.005 & 3696 & Statistics Sweden \\
\hline Proportion 00-14 (\%) & 17.571 & 2.184 & 1.846 & 1.176 & 3696 & Statistics Sweden \\
\hline Proportion $15-19(\%)$ & 6.708 & 0.753 & 0.479 & 0.583 & 3696 & Statistics Sweden \\
\hline Proportion $20-24(\%)$ & 5.077 & 1.096 & 1.015 & 0.412 & 3696 & Statistics Sweden \\
\hline Proportion $25-34(\%)$ & 10.678 & 2.188 & 1.962 & 0.969 & 3696 & Statistics Sweden \\
\hline Proportion 35-44 (\%) & 13.328 & 1.312 & 1.217 & 0.497 & 3696 & Statistics Sweden \\
\hline Ln. of income & 5.217 & 0.130 & 0.109 & 0.071 & 3696 & Statistics Sweden \\
\hline Total unemployment (\%) & 5.762 & 2.382 & 1.888 & 1.452 & 3696 & $\begin{array}{l}\text { National Labour Market } \\
\text { Board }\end{array}$ \\
\hline $\begin{array}{l}\text { Long-term unemployment } \\
\text { (\%) }\end{array}$ & 1.338 & 0.647 & 0.423 & 0.490 & 3696 & Statistics Sweden \\
\hline Youth unemployment & 17.524 & 5.510 & 4.339 & 3.398 & 3696 & Statistics Sweden \\
\hline Ln. of exp. on education & 9.435 & 0.130 & 0.099 & 0.084 & 3696 & Statistics Sweden \\
\hline Ln. of exp. on social aid & 7.599 & 0.354 & 0.302 & 0.184 & 3696 & Statistics Sweden \\
\hline $\begin{array}{l}\text { Ln. of exp. on culture and } \\
\text { leisure }\end{array}$ & 7.497 & 0.258 & 0.236 & 0.107 & 3696 & Statistics Sweden \\
\hline Alcohol consumption & 4.988 & 4.389 & 4.110 & 1.637 & 3696 & $\begin{array}{l}\text { The Swe. National Institute } \\
\text { of Public Health }\end{array}$ \\
\hline Grades & 13.641 & 0.899 & 0.750 & 0.602 & 2704 & $\begin{array}{l}\text { The Swedish National } \\
\text { Agency for Education }\end{array}$ \\
\hline Proportion in private schools & 9.159 & 8.924 & 7.028 & 5.833 & 2704 & $\begin{array}{l}\text { The Swedish National } \\
\text { Agency for Education }\end{array}$ \\
\hline Foreign proportion at schools & 11.684 & 8.165 & 8.258 & 2.459 & 2699 & $\begin{array}{l}\text { The Swedish National } \\
\text { Agency for Education }\end{array}$ \\
\hline Ln. Burglary & 6.984 & 0.407 & 0.298 & 0.278 & 3696 & $\begin{array}{l}\text { The National Council for } \\
\text { Crime Prevention }\end{array}$ \\
\hline Ln. theft and pilfering & 7.282 & 0.415 & 0.383 & 0.157 & 3696 & $\begin{array}{l}\text { The National Council for } \\
\text { Crime Prevention }\end{array}$ \\
\hline Ln. handling stolen property & 3.340 & 0.737 & 0.420 & 0.602 & 3227 & $\begin{array}{l}\text { The Nat. Council for Crime } \\
\text { Prevention }\end{array}$ \\
\hline Ln. theft from vehicles & 6.850 & 0.517 & 0.369 & 0.362 & 3696 & $\begin{array}{l}\text { The National Council for } \\
\text { Crime Prevention }\end{array}$ \\
\hline Ln. assault & 6.290 & 0.458 & 0.360 & 0.284 & 3696 & $\begin{array}{l}\text { The National Council for } \\
\text { Crime Prevention }\end{array}$ \\
\hline Ln. rape & 3.170 & 0.744 & 0.338 & 0.666 & 3181 & $\begin{array}{l}\text { The National Council for } \\
\text { Crime Prevention }\end{array}$ \\
\hline Ln. robbery & 3.439 & 0.813 & 0.657 & 0.466 & 3138 & $\begin{array}{l}\text { The National Council for } \\
\text { Crime Prevention }\end{array}$ \\
\hline Ln. alcohol or narcotics & 5.672 & 1.021 & 0.707 & 0.745 & 3654 & $\begin{array}{l}\text { The National Council for } \\
\text { Crime Prevention }\end{array}$ \\
\hline
\end{tabular}




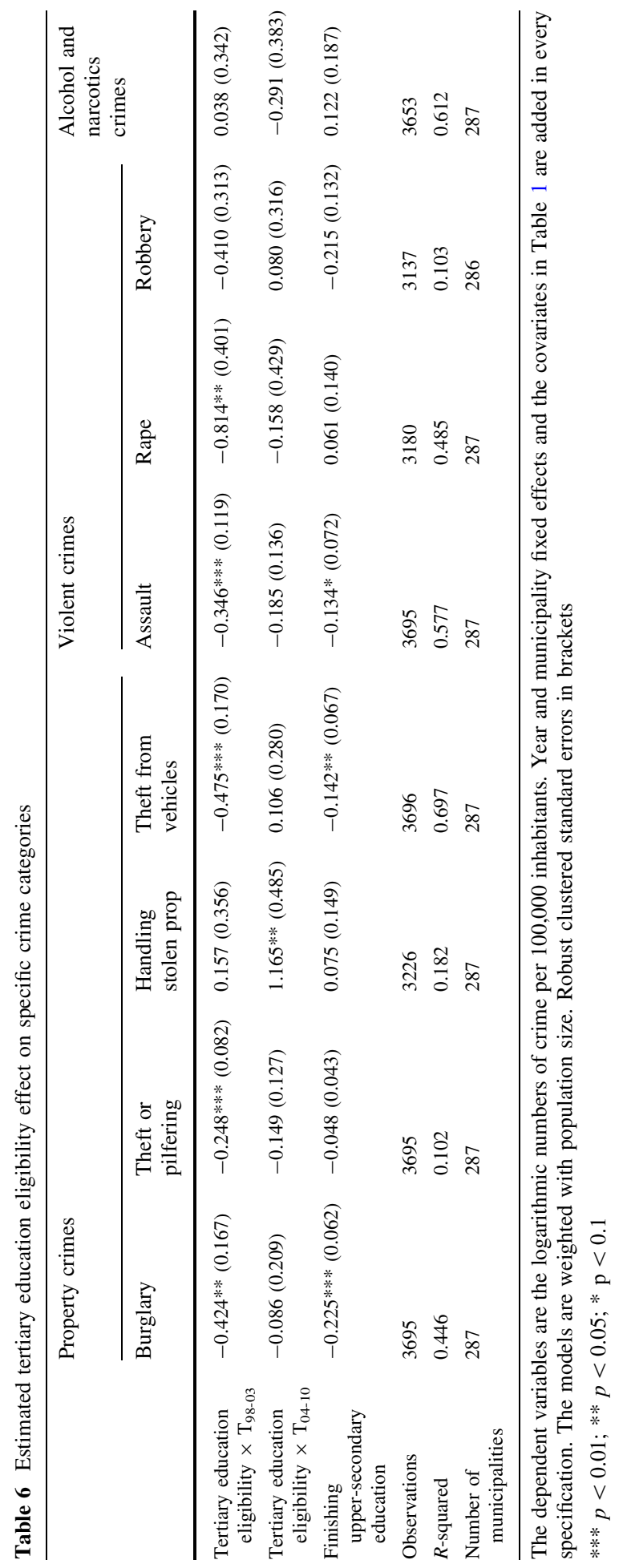




\section{References}

Anderson M (2014) In school and out of trouble? The minimum dropout age and juvenile crime. Rev Econ Stat 96(2):318-331

Åslund O, Grönqvist H, Hall C, Vlachos J (2012) Education and criminal behavior: insights from an expansion of upper secondary school. In: EALE conference paper

Baker O, Lang K (2013) The effect of high school exit exams on graduation, employment, wages and incarceration. In: NBER Working Paper No. 19182

Becker G (1968) Crime and punishment: an economic approach. J Pol Econ 76:169-217

Bell D, Blanchflower D (2011) Youth unemployment in Europe and the United States. Nord Econ Pol Rev $1: 11-38$

Björklund A, Fredriksson P, Gustafsson J-E, Öckert B (2010) Den svenska utbildningspolitikens arbetsmarknadseffekter: vad säger forskningen? IFAU Rapport 2010:13

Card D (1999) The causal effect of education on earnings. In: Ashenfelter O, Card D (eds) Handbook of labour economics. Elsevier Science, Oxford, pp 1801-1863

Cliffordson C (2004) Betygsinflation i de målrelaterade Gymnasiebetygen. Ped Forsk Sve 9(1):1-14

Deming D (2011) Better schools, less crime? Quart J Econ 126:2063-2115

Ellwood D (1982) Teenage unemployment: permanent scars or temporary blemishes. In: Freeman R, Wise D (eds) The youth labor market problem: its nature causes and consequences. University of Chicago Press, Chicago, pp 349-390

Felson M (1998) Crime and everyday life. Pine Forge Press, Thousand Oaks

Gould E, Weinberg B, Mustard D (2002) Crime rates and local labor market opportunities in the United States: 1979-1997. Rev Econ Stat 84(1):45-61

Grogger F (1998) Market wage and youth crime. J Lab Econ 16:756-791

Grönqvist H (2011) Youth unemployment and crime: new lessons exploring longitudinal register data. Working Paper 7/2011, (SOFI), Stockholm University

Gustafsson J-E, Yang Hansen K (2009) Resultatförändringar i svensk grundskola. In: Vad påverkar resultaten i svensk grundskola? Kunskapsöversikt om betydelsen av olika faktorer, Skolverkets rapport, pp 40-85

Hansen K (2003) Education and the crime-age profile. Brit J Crim 43:141-168

Hirschi T (1969) Causes of delinquency. University of California Press, Berkely

Hirschi T, Gottfredson M (1983) Age and the explanation of crime. Am J Soc 89(3):552-584

Hjalmarsson R (2008) Criminal justice involvement and high school completion. J Urb Econ 63:613-630

Hjalmarsson R, Holmlund H, Lindquist M (2013) The effect of education on criminal convictions and incarceration: causal evidence from micro-data, Working Paper

Jacob B, Lefgren L (2003) Are idle hands the devil's workshop? Incapacitation, concentration and juvenile crime. Am Econ Rev 93:1560-1577

Lin M-J (2008) Does unemployment increase crime? Evidence from U.S. data 1974-2000. J Hum Resour 43(2):413-436

Lochner L (2004) Education, work, and crime: a human capital approach. Int Econ Rev 45:811-843

Lochner L (2010) Education and crime. In: Peterson P, Bake E, McGaw B (eds) International encyclopedia of education, 3rd edn. Elsevier, Amsterdam, pp 239-244

Lochner L, Moretti E (2004) The effect of education on crime: evidence from prison inmates, arrests and self-reports. Am Econ Rev 94:155-189

Luallen J (2006) School's out......forever: a study of juvenile crime, at-risk youths and teacher strikes. J Urb Econ 59:75-103

Machin S, Meghir C (2004) Crime and economic incentives. J Hum Resour 39(4):958-979

Machin S, Marie O, Vujić S (2011) The crime reducing effect of education. Econ J 121(552):463-484

Machin S, Marie O, Vujić S (2012) Youth crime and education expansion. Germ Econ Rev 13:366-384

Mustard D (2010) How do labor markets affect crime? New evidence on an old puzzle. In: Benson B, Zimmerman P (eds) Handbook on the economics of crime. Edward Elgar Publishing, Cheltenham, pp 342-358

NCCP (2008) Brottsutvecklingen i Sverige fram till år 2007. Report 2008:23. Stockholm: The National Council for Crime Prevention

Nordström Skans O (2011) Scarring effects of the first labor market experience. IZA DP No. 5565

Oreopoulos P (2007) Do dropouts drop out too soon? Wealth, health and happiness from compulsory schooling. J Pub Econ 91:2213-2229

Rege M, Skardhamar T, Telle K, Votruba M (2009) The effect of plant closure on crime. Discussion Papers No. 593. Statistics Norway, Research Department 
Sabates R (2008) Educational attainment and juvenile crime. Area-level analysis using three cohorts of young people. Brit J Crim 48:395-409

Sabates R (2009) Educational expansion, economic growth and antisocial behaviour: evidence from England. Educ Stud 36:165-173

Sabates R, Feinstein L (2008) Effects of government initiatives on youth crime. Ox Econ Pap 60:462-483

Skolverket (2012) Betygsinflation-betygen och den faktiska kunskapsutvecklingen. Dnr 2012:387

Solon G, Haider S, Wooldridge J (2015) What are we weighting for? J Hum Resour 50:301-316

Tauchen H, Witte A, Griesinger H (1994) Criminal deterrence: revisiting the issue with a birth cohort. Rev Econ Stat 76:399-412

Vlachos J (2010) Betygets värde. En analys av hur konkurrens påverkar betygssättningen vid svenska skolor. Konkurrensverket rapport 2010:6

Wikström C, Wikström M (2005) Grade inflation and school competition. An empirical analysis based on the Swedish upper secondary schools. Econ Educ Rev 24(3):309-322

Wooldridge J (2013) Introductory econometrics: a modern approach, 5th edn. South-Western, Mason 